\title{
FUNGICIDE RESISTANCE AND GENETIC VARIABILITY IN PLANT PATHOGENIC STRAINS OF GUIGNARDIA CITRICARPA
}

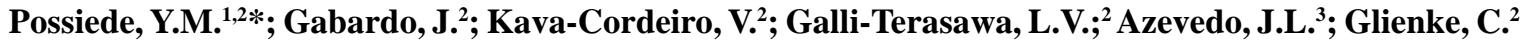 \\ ${ }^{1}$ Departamento de Biologia, Universidade Federal de Mato Grosso do Sul, Campo Grande, MS, Brasil; ${ }^{2}$ Departamento de \\ Genética, Universidade Federal do Paraná, Curitiba, PR, Brasil; ${ }^{3}$ Departamento de Genética, Escola Superior de Agricultura \\ "Luiz de Queiroz", Universidade de São Paulo, Piracicaba, SP, Brasil
}

Submitted: June 20, 2008; Returned to authors for corrections: September 05, 2008; Approved: March 31, 2009.

\begin{abstract}
Citrus black spot (CBS) is a plant disease of worldwide occurrence, affecting crops in Africa, Oceania, and South America. In Brazil, climate provides favorable conditions and CBS has spread to the Southeast and South regions. CBS is caused by the fungus Guignardia citricarpa (anamorph: Phyllosticta citricarpa) and its control is based on the use of fungicides, such as benzimidazoles. In South Africa, the disease was kept under control for 10 years with benomyl, until cases of resistance to high concentrations of this fungicide were reported from all citrus-producing areas. Azoxystrobin (a strobilurin) has been found effective in controlling phytopathogens, including CBS, in a wide range of economically important crops. The present study investigated in vitro the effects of the fungicides benomyl and azoxystrobin on 10 strains of G. citricarpa isolated from lesions in citrus plants from Brazil and South Africa. Benomyl at $0.5 \mu \mathrm{g} / \mathrm{mL}$ inhibited mycelial growth in all strains except PC3C, of African origin, which exhibited resistance to concentrations of up to $100.0 \mu \mathrm{g} / \mathrm{mL}$. The spontaneous mutation frequency for resistance to benomyl was $1.25 \times 10^{-7}$. Azoxystrobin, even at high concentrations, did not inhibit mycelial growth in any of the strains, but significantly reduced sporulation rates, by as much as $100 \%$, at a concentration of $5.0 \mu \mathrm{g} / \mathrm{mL}$. Variations in sensitivity across strains, particularly to the strobilurin azoxystrobin, are possibly related to genetic variability in G. citricarpa isolates.
\end{abstract}

Key words: G. citricarpa, Azoxystrobin, Benomyl, Citrus black spot, Fungicides

\section{INTRODUCTION}

Citrus black spot (CBS), caused by the fungus Guignardia citricarpa (anamorph: Phyllosticta citricarpa), was first reported in 1895 from Australia, in 1925 from South Africa, and in 1940 from Brazil. Currently, the disease has worldwide occurrence, affecting crops in Africa, Oceania and South America (2). In Brazil, where climate provides favorable conditions for the disease, CBS has spread to the entire Southeast Region and most of the South Region, being also found in the northern state of Amazonas (8).

Pomelos, lemons, some varieties of mandarines, and all varieties of sweet oranges are affected by the disease, developing lesions on the rind that downgrade the fruit, but do not impair its internal quality. In more severe cases, however, premature fruit drop may occur. Rind blemishes make the fruits unfit for fresh-fruit market, whereas premature drop reduces crop yield $(7,13,16)$.

Plant disease control is primarily based on the use of fungicides. However fungicides pose serious difficulties for disease control. They are selective compounds, as their action is concentrated primarily on one or a few sites in the cellular metabolism - a feature that increases not only their effectiveness, but also the risk for development of resistance $(10,15)$. According to Dekker (6), such selectivity explains the genetic changes that lead to development of pathogen

*Corresponding Author. Mailing address: Departamento de Biologia, UFMS. Caixa Postal 549, Campo Grande, MS 79070-900, Brazil. Tel./fax (67) 3345-7322. E-mail: ympossiede@gmail.com 
resistance to a fungicide. One single genetic change may be enough to result in a high degree of resistance. The cases of resistance most frequently reported have been related to this particular.

In Brazil, control of the CBS pathogen has been attained with the use of protective fungicides based on copper or dithiocarbamates and systemic fungicides (such as benzimidazoles), in combination or not, and associated or not with vegetable or mineral oils. Control procedures are carried out in accordance with data generated by CBS control programs from other countries, particularly South Africa $(13,16)$.

In South Africa, 20 years after the first records, CBS had spread to the main citrus-producing areas, causing losses of over $90 \%$ in fruit production (7). Initially endemic, the disease was kept under control for 10 years with the use of benomyl, until cases were reported of resistance to high concentrations of this fungicide (14). Such resistance is now found in all major citrus-producing areas in South Africa (26).

Recently, natural strobilurin fungicides developed from a $\beta$-methoxyacrylate of the agaric Strobilurus tenacellus were shown to have fungicidal activity against a wide range of economically important crop pathogens, including G. citricarpa (25), and against all four major groups of plant pathogenic fungi (3). Azoxystrobin, which has been successfully used in South Africa to control the disease in areas where resistance to benomyl has been reported, is now registered in the country for CBS control (26).

In the literature, few data are available on the effects of the fungicides azoxystrobin and benomyl in vitro on the fungus $G$. citricarpa, such as mycelial growth, sporulation, and mutation frequency for resistance development. The purpose of the present investigation was to determine the fungus sensitivity to the fungicides azoxystrobin (a strobilurin) and benomyl (a benzimidazole), the spontaneous mutation frequency for resistance to benomyl, and changes in sporulation rate after treatment with azoxystrobin. The study also evaluated the relation between genetic dissimilarity of strains and range of responses to those fungicides.

\section{MATERIALS AND METHOD}

\section{Strains}

Pathogenic strains of G. citricarpa and endophytic strains of G. mangiferae and Phyllosticta spinarum used in this study are from the collection of the Laboratory of Microorganism Genetics of Universidade Federal do Paraná (UFPR), Curitiba, Brazil (Table 1). All isolates were purified as monosporic colonies grown on Pontecorvo medium, designated CM (20), modified by Azevedo \& Costa 1973 (1). Stocks were prepared by seeding the strains on plates containing agar-water medium (15.0 g agar, $1000 \mathrm{~mL}$ distilled water, $\mathrm{pH} 5.8$ ) in the vicinity of the edges of previously sterilized citrus leaf fragments distributed on the
Table 1. Guignardia citricarpa strains assayed (11).

\begin{tabular}{|c|c|c|}
\hline Strains & Host & Provenance \\
\hline $\begin{array}{l}\text { PC13/96 } \\
\text { PC7LD6, PC7LB6, } \\
\text { PC7LF2,PC7LB8, }\end{array}$ & Citrus limonum & $\begin{array}{l}\text { Mogi-Guaçu county, } \\
\text { São Paulo, Brazil }{ }^{(1)}\end{array}$ \\
\hline PC7LE10 & Citrus sinensis & $\begin{array}{l}\text { Mogi-Guaçu county, } \\
\text { São Paulo, Brazil }{ }^{(1)}\end{array}$ \\
\hline PCP6 & Citrus spp. & $\begin{array}{l}\text { Cordeirópolis county, } \\
\text { São Paulo, Brazil }{ }^{(1)}\end{array}$ \\
\hline PC3C, $\mathrm{PC} 6 \mathrm{C}$ & Citrus spp. & South Africa ${ }^{(2)}$ \\
\hline $\mathrm{PC} 12 \mathrm{C}$ & Citrus spp. & Brazil $^{(2)}$ \\
\hline EC41/99 & Citrus reticulata & $\begin{array}{l}\text { Mogi-Guaçu county, } \\
\text { São Paulo, Brazil }{ }^{(1)}\end{array}$ \\
\hline ECOL23 & Citrus sinensis & $\begin{array}{l}\text { Olímpia county, } \\
\text { São Paulo, Brazil }\end{array}$ \\
\hline ECN22 & Citrus sinensis & $\begin{array}{l}\text { Novais county, } \\
\text { São Paulo, Brazil }{ }^{(3)}\end{array}$ \\
\hline $\begin{array}{l}\text { ECPR3,ECPR5, } \\
\text { ECPR6,ECPR8, } \\
\text { ECPR10 }\end{array}$ & Citrus limonum & $\begin{array}{l}\text { Rio Negro county, } \\
\text { Paraná, Brazil }{ }^{(3)}\end{array}$ \\
\hline
\end{tabular}

${ }^{1}$ Strains isolated by Carlos Ivan Aguilar Vildoso. Graciously supplied by Citricultura Sylvio Moreira Center, Agronomic Institute of Campinas (IAC), Cordeirópolis, SP, Brazil, and by the Laboratory of Microbial Genetics of ESALQ-USP, Piracicaba, SP, Brazil;

${ }^{2}$ Strains graciously supplied in 2001 by Dr. George Carroll of the University of Oregon, USA;

${ }^{3}$ Strains isolated by Chirlei Glienke. Graciously supplied by the Laboratory of Microbial Genetics of ESALQ-USP, Piracicaba, SP, Brazil.

medium surface. After a 21-day growth period at $28^{\circ} \mathrm{C}$, the leaf fragments already covered with mycelia and spores were transferred to Eppendorf vials containing sterilized silica and stored at $4^{\circ} \mathrm{C}(4)$.

\section{Fungicides}

The fungicides tested were azoxystrobin (Amistar 80\% WP, Syngenta) and benomyl (Benlate 50\% WP, Du Pont). For each fungicide, $1.0 \mathrm{mg} / \mathrm{mL}$ of active principle stock solutions was prepared in $100.0 \mathrm{~mL}$ of distilled water just before using. For benomyl, it was first dissolved on $5.0 \mathrm{~mL}$ of acetone.

\section{Determination of sensitivity of $G$ citricarpa to benomyl and azoxystrobin}

This was determined by measuring colony diameter 15 days after inoculation in Petri dishes containing fungicide at increasing concentrations in the range of 0.1 to $10.0 \mu \mathrm{g} / \mathrm{mL}$ mixed into melted CM medium. Each dish was point-inoculated with three equidistant inocula of $4 \mathrm{~mm}$ in diameter harvested from the edges 
of 20-day-old colonies. Colony diameter was defined as the average of two orthogonal width measurements.

A fully randomized design was adopted for the experiment, with three repetitions, each of them consisting of two plates for each fungicide concentration per isolate investigated and two control plates containing full culture medium alone.

\section{Azoxystrobin and sporulation rate}

Azoxystrobin was also tested for its ability to interfere with spore production. Conidia were inoculated on $\mathrm{CM}$ and 15 days after inoculation, $5.0 \mathrm{~mL}$ of an aqueous solution of Tween 80 $(0.1 \% \mathrm{v} / \mathrm{v})$ were added onto the plates, and thus covered with surfactant and were incubated at $4^{\circ} \mathrm{C}$ for $24 \mathrm{~h}$, after which period the liquid phase was separated and the precipitate was centrifuged $(2310 \mathrm{~g})$ and suspended in $1.0 \mathrm{~mL} 0.85 \% \mathrm{NaCl}$ solution. Conidial concentration was estimated using a Neubauer chamber.

A randomized block design was adopted, using five blocks with six repetitions each.

\section{Benomyl-resistant mutants}

A spore suspension $\left(10^{6}\right.$ spores $\left./ \mathrm{mL}\right)$ from the $\mathrm{PC} 13 / 96$ strain was plated on full culture medium containing increasing fungicide concentrations $(0.1,0.2,0.3,0.4$, and $0.5 \mu \mathrm{g} / \mathrm{mL})$. Plates containing fungicide-free full culture medium, in the same number as those with fungicide, were used as controls. The mutation frequency was calculated by comparing the number of surviving colonies grown on medium containing fungicide with those grown on control plates. The experiment was conducted with three repetitions.

\section{Preparation of DNA samples}

Conidia from the strains were inoculated at several points on a Petri dish containing full medium culture. After four days the colonies were carefully removed without medium, lyophilized, frozen in liquid nitrogen, and ground to a fine powder. Nucleic acids were extracted using the process described by Raeder \& Broda 1985 (21) and modified by Glienke-Blanco et al. 2002 (12) and separated by electrophoresis in $1 \%$ agarose gel stained with ethidium bromide $(0.5 \mu \mathrm{g} / \mathrm{mL})$ at $3 \mathrm{~V} / \mathrm{cm}$.

\section{RAPD analysis}

Random Amplified Polymorphic DNA (RAPD) analysis was carried out using $50 \mathrm{ng}$ genomic DNA. The amplification reaction was done in a $25-\mu \mathrm{L}$ final volume containing 1.4 units of Taq DNA polymerase, $0.4 \mu \mathrm{M}$ primer, $0.2 \mathrm{mMdNTPs}, 3.0 \mathrm{mM} \mathrm{MgCl}_{2}$, and 1X Reaction Buffer (Life Technologies, Alameda, CA, USA). Negative controls containing all components except genomic DNA were included in all experiments. The primers selected OPX12 (TCGCCAGCCA), OPX19 (TGGCAAGGCA), OPQ4 (AGTGCGCT A) - were obtained from Operon Technologies (Alameda, CA, USA). Amplification was performed in an MJ
Research thermocycler (Watertown, MA, USA) in the following steps: initial 4-min denaturation at $92^{\circ} \mathrm{C}$, followed by 40 cycles, each composed of 1-min denaturation at $92^{\circ} \mathrm{C}, 1.5$-min annealing at $37^{\circ} \mathrm{C}$, and $2-\mathrm{min}$ extension at $72^{\circ} \mathrm{C}$, and a final $3-$ min extension at $72^{\circ} \mathrm{C}$.

\section{Data analysis}

RAPD markers were interpreted as binary data based on the presence or absence of bands. A matrix of Jaccard genetic similarities (28) was generated using NTSYS 2.1 (24). A significance test of the correlation between the genetic similarity matrix and a cophenetic matrix of the dendrogram was carried out using the Mantel test of matrix correspondence (17). From the genetic similarity matrix, a Principal Coordinate Analysis (PCO) was performed to verify possible clustering of isolates. Based on similarity values, an UPGMA dendrogram was produced. The robustness of each node in the dendrogram was evaluated by bootstrap analysis (9) using the software Bood v.3.03 (5).

\section{RESULTS AND DISCUSSION}

\section{Resistance to azoxystrobin}

The strains used were able to grow in all tested concentrations of azoxystrobin till $10.0 \mu \mathrm{g} / \mathrm{mL}$ (Table 2). Nonetheless, various growth patterns were observed, with considerable decrease in spore production (Table 3). Although azoxystrobin did not entirely inhibit mycelial growth, a considerable reduction in sporulation rate was found for all the strains investigated at concentrations of $1.0 \mu \mathrm{g} / \mathrm{mL}$, except for the strains of South Africa - a valuable feature, since this is the form of dissemination of the pathogen investigated $(7,22)$. At

Table 2. Sensitivity (measured as percent reduction in colony diameter) of 15-day-old colonies of G. citricarpa strains grown at $28^{\circ} \mathrm{C}$ on full culture medium containing azoxystrobin at three concentrations.

\begin{tabular}{|c|c|c|c|}
\hline Strain & $1.0 \mu \mathrm{g} / \mathrm{mL}$ & $5.0 \mu \mathrm{g} / \mathrm{mL}$ & $10.0 \mu \mathrm{g} / \mathrm{mL}$ \\
\hline РCP6 & $42.93 \mathrm{a}^{1}$ & $48.66 \mathrm{a}$ & $44.88 \mathrm{a}$ \\
\hline PC12C & $40.28 \mathrm{ab}$ & $40.26 \mathrm{ab}$ & $37.63 \mathrm{ab}$ \\
\hline PC7LD6 & $32.69 \mathrm{bcd}$ & $38.40 \mathrm{bc}$ & $35.93 \mathrm{ab}$ \\
\hline PC7LB8 & 33.70 abc & $30.78 \mathrm{~cd}$ & 29.91 bcde \\
\hline PC7LE10 & $29.90 \mathrm{~cd}$ & $27.45 \mathrm{de}$ & 26.04 cde \\
\hline PC7LF2 & $29.04 \mathrm{~cd}$ & $27.07 \mathrm{de}$ & $34.81 \mathrm{bc}$ \\
\hline PC13/96 & $24.27 \mathrm{de}$ & $27.26 \mathrm{de}$ & $30.86 \mathrm{bcd}$ \\
\hline PC7LB6 & 27.70 cde & $23.98 \mathrm{def}$ & 24.31 def \\
\hline PC3C & 19.27 ef & 20.80 ef & 21.18 ef \\
\hline PC6C & $11.26 \mathrm{f}$ & $14.88 \mathrm{f}$ & $16.63 \mathrm{f}$ \\
\hline
\end{tabular}

${ }^{1}$ Values followed by the same letter on the same column do not differ significantly (Tukey's test, $5 \%$ probability). 
Table 3. Sensitivity (measured as percent reduction in spore production) of strains of $\mathrm{G}$. citricarpa in $\mathrm{CM}$ with a range of azoxystrobin concentrations, after 15 days of incubation at $28^{\circ} \mathrm{C}$.

\begin{tabular}{lcr}
\hline Strain & $\mathbf{1 . 0} \boldsymbol{\mu g} / \mathbf{m L}$ & $\mathbf{5 . 0} \boldsymbol{\mu g} / \mathbf{m L}$ \\
\hline PC3C & $26.00 \mathrm{~b}^{1}$ & $91.75 \mathrm{a}$ \\
PC6C & $25.00 \mathrm{~b}$ & $75.00 \mathrm{a}$ \\
PC12C & $96.85 \mathrm{a}$ & $93.90 \mathrm{a}$ \\
PC7LD6 & $100.00 \mathrm{a}$ & $100.00 \mathrm{a}$ \\
PC7LB6 & $98.00 \mathrm{a}$ & $100.00 \mathrm{a}$ \\
PC7LB8 & $96.95 \mathrm{a}$ & $95.55 \mathrm{a}$ \\
PC7LE10 & $99.05 \mathrm{a}$ & $100.00 \mathrm{a}$ \\
PC7LF2 & $100.00 \mathrm{a}$ & $100.00 \mathrm{a}$ \\
PCP6 & $98.45 \mathrm{a}$ & $100.00 \mathrm{a}$ \\
PC13/96 & $97.65 \mathrm{a}$ & $98.55 \mathrm{a}$ \\
\hline
\end{tabular}

${ }^{1}$ Values followed by the same letter on the same columns do not differ significantly ( $\mathrm{T}$ test, $5 \%$ probability).

azoxystrobin concentration of $10.0 \mu \mathrm{g} / \mathrm{mL}$, spore production rates fell by $100 \%$, irrespective of strain, including isolates PC3C and PC6C.

Spore production is quite variable among strains, hindering comparisons of the fungicide effect. When we used the RAPD molecular marker (Fig. 1), different responses to azoxystrobin were elicited from strains of great genetic similarity, such as PC13/96, PCP6, and the South African strains PC3C e PC6C, which belong to the same subgroup.

On the other hand, between strains PC7LF2 and PC7LD6; and between PC13/96 and PC7LB8, despite exhibiting similar susceptibilities to azoxystrobin, are less genetically similar, as shown by the distinct subgroups they pertain to. Irrespective of the genetic variability across isolates in group A, all of them belong to the species $G$. citricarpa, since groups B and $\mathrm{C}$ are composed of G. mangiferae and Phyllosticta spinarum strains, respectively. Such G. mangiferae and Phyllosticta spinarum isolates were considered as outgroupings for purposes of comparison with the G. citricarpa strains investigated (Fig. 1).

\section{Resistance to benomyl}

Of the ten strains tested, all isolates obtained from CBS lesions on fruits collected from orchards in the state of São Paulo, Brazil, were sensitive to benomyl at low concentrations, as revealed by a $100 \%$ reduction in mycelial growth when the fungicide was used at $0.5 \mu \mathrm{g} / \mathrm{mL}$ (Table 4). Of the two strains from South Africa, PC6C showed responses similar to those from Brazilian strains, despite its significantly more pronounced growth in comparison with all other strains at the concentration of $0.1 \mu \mathrm{g} / \mathrm{mL}$ (Table 4). On the other hand, another South African strain, PC3C, behaved in a completely different manner, exhibiting

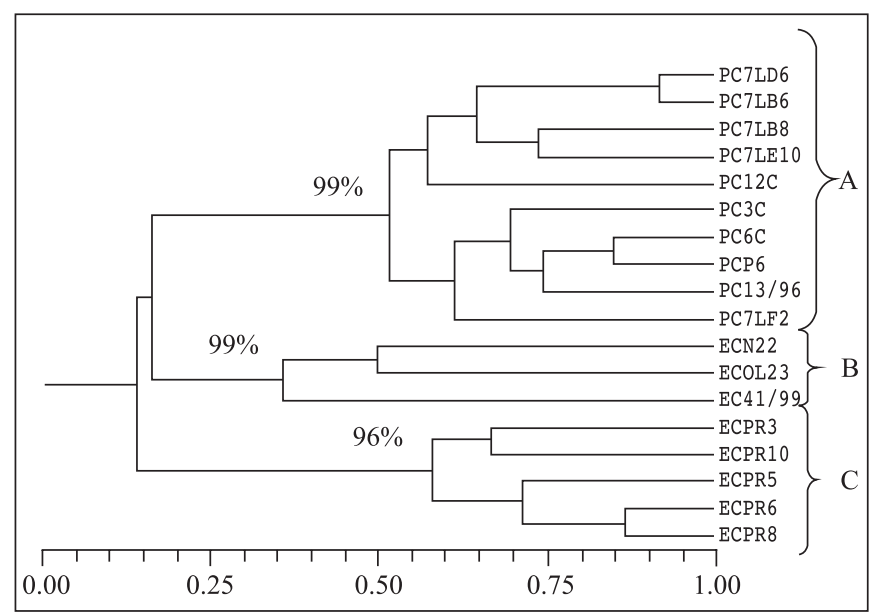

Figure 1. Genetic similarity dendrogram, by RAPD analysis, of isolates of G. citricarpa, G. mangiferae (ECN22, ECOL23 and EC41/99), and Phyllosticta spinarum. (ECPR3, ECPR5, ECPR6, ECPR8 and ECPR10) (11). Percentages shown on the left of nodes are bootstrap values based on 10.000 resamplings.

Table 4. Mycelial growth $(\mathrm{cm})$ in 15-day-old colonies of $G$. citricarpa strains grown at $28^{\circ} \mathrm{C}$ on full culture medium containing increasing concentrations of benomyl.

\begin{tabular}{lcccc}
\hline Strain & Control & $\mathbf{0 . 1} \mathbf{~ m g} / \mathbf{m L}$ & $\mathbf{0 . 5} \mathbf{~ m g / m L}$ \\
\hline PC6C & $4.15556 \mathrm{a}^{1}$ & $1.00000 \mathrm{c}$ & $0.00000 \mathrm{~b}$ \\
PC3C & $3.65278 \mathrm{~b}$ & $3.65278 \mathrm{a}$ & $3.63056 \mathrm{a}$ \\
PC7LE10 & $3.57778 \mathrm{~b}$ & $1.28889 \mathrm{bc}$ & $0.00000 \mathrm{~b}$ \\
PC12C & $3.47778 \mathrm{bc}$ & $2.04445 \mathrm{~b}$ & $0.00000 \mathrm{~b}$ \\
PC7LB8 & $3.30556 \mathrm{bcd}$ & $1.33889 \mathrm{bc}$ & $0.00000 \mathrm{~b}$ \\
PC7LD6 & $3.22778 \mathrm{bcd}$ & $2.04445 \mathrm{~b}$ & $0.00000 \mathrm{~b}$ \\
PC13/96 & $3.22778 \mathrm{bcd}$ & $2.03889 \mathrm{~b}$ & $0.00000 \mathrm{~b}$ \\
PC7LB6 & $3.21667 \mathrm{bcd}$ & $1.43333 \mathrm{bc}$ & $0.00000 \mathrm{~b}$ \\
PC7LF2 & $3.00556 \mathrm{~cd}$ & 1.57222 & $\mathrm{bc}$ & $0.00000 \mathrm{~b}$ \\
PCP6 & $2.87222 \mathrm{~d}$ & 1.31111 & $\mathrm{bc}$ & $0.00000 \mathrm{~b}$ \\
\hline
\end{tabular}

${ }^{1}$ Values followed by the same letter on the same column do not differ significantly (Tukey's test, $5 \%$ probability).

growth up to the maximum concentration tested, with a discrete decrease, somewhat greater than $20 \%$, in mycelial growth only at concentrations of $10.0 \mu \mathrm{g} / \mathrm{mL}$ and higher - i.e., at concentrations 100 times higher than that sufficient to inhibit growth in all other strains (Fig. 2).

Benomyl is a member of the benzimidazoles, a group for which wider knowledge is available on the genetic features involved in fungicide resistance, which may be determined by 


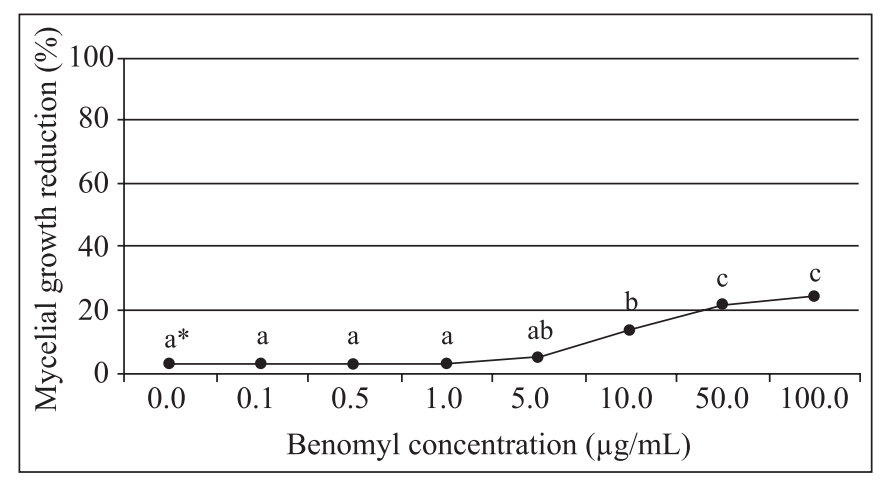

Figure 2. Reduction in mycelial growth (\%) in 15-day-old colonies of G. citricarpa $\mathrm{PC} 3 \mathrm{C}$ strain grown at $28^{\circ} \mathrm{C}$ on full culture medium containing increasing concentrations of benomyl. "Values followed by the same letter do not differ significantly (Tukey's test, $5 \%$ probability).

one single or a few genes (10), resulting in changes to the protein tubulin. Resistance to benzimidazoles in Aspergillus nidulans, Neurospora crassa, and Saccharomyces cerevisae derives from mutations to the gene encoding $\beta$-tubulin $(19,27,29)$.

Resistance to benomyl has become more prevalent and is now present in all the important citrus-producing areas in southern Africa (26). In Brazil, Martins et al. 1998 (18) published the first case of G. citricarpa resistance to benomyl in citrus plants. In addition, isolates of G. citricarpa from lesions on Citrus sinensis fruits exhibited resistance to different concentrations of carbendazim, also a fungicide of the benzimidazole group (23).

The spontaneous mutation frequency for resistance to benomyl was tested for the sensitive strain PC13/96, yielding mutants resistant to a concentration up to $0.10 \mu \mathrm{g} / \mathrm{mL}$ and a mutation frequency of $1.25 \times 10^{-7}$ in three experiments. In two experiments, Van Tuyl 1977 (30) found a spontaneous mutation frequency of $2 \times 10^{-9}$ for resistance to benomyl in Aspergillus nidulans, using a fungicide concentration of $2.0 \mu \mathrm{g} / \mathrm{mL}$. Such low frequencies of spontaneous mutation for resistance to benomyl seem to corroborate the view that the emergence of resistance is strongly dependent on continued use of a fungicide, despite doubts on whether differences in spontaneous mutation rates play a significant role in the appearance of resistance under field conditions (30).

In the present investigation, no G. citricarpa strains, whether or not resistant to benomyl (a benzimidazole), exhibited resistance to azoxystrobin (a strobilurin). Each fungicide had its own manner of controlling the pathogen, with benzomidazole inhibiting mycelial growth and strobilurin inhibiting spore production. Variations in sensitivity to fungicides observed across strains, particularly with the strobilurin azoxystrobin, are possibly related to the genetic variability of $G$. citricarpa isolates.

\section{RESUMO
Resistência a fungicidas e variabilidade genética em linhagens patogênicas de plantas Guignardia citricarpa}

A Mancha Preta dos Citros (MPC) tem ocorrência mundial afetando a produção de citros na África, Oceania e América do Sul. No Brasil, onde o clima é favorável ao seu desenvolvimento, a doença está espalhada nas regiões Sul e Sudeste. O controle da MPC, causada pelo fungo Guignardia citricarpa (anamorfo: Phyllosticta citricarpa) é baseado na aplicação de fungicidas, como os benzimidazóis. Na África do Sul, após 10 anos de controle da doença com o fungicida benomil, os casos de resistência a altas concentrações deste fungicida atingiram todas as áreas produtoras. $\mathrm{O}$ fungicida estrolilurina chamado azoxistrobina tem se mostrado eficiente no controle dos fitopatógenos de uma grande variedade de culturas economicamente importantes, incluindo a MPC. Neste trabalho foram investigados os efeitos in vitro dos fungicidas benomil e azoxistrobina em 10 linhagens de G. citricarpa isoladas de lesões em plantas cítricas no Brasil e na África do Sul. Houve inibição do crescimento micelial a $0,5 \mu \mathrm{g} / \mathrm{mL}$ do fungicida benomil entre as linhagens testadas, com exceção de PC3C de origem sul-africana, que apresentou resistência até a concentração de 100,0 $\mu \mathrm{g} / \mathrm{mL}$ de benomil. A frequiência de mutação espontânea para resistência ao benomil foi de $1,25 \times 10^{-7}$. A estrobilurina azoxistrobina, mesmo em altas concentrações, não inibiu o crescimento micelial dos isolados, entretanto reduziu significativamente a produção de esporos, chegando a $100 \%$ de inibição em concentrações de 5,0 $\mu \mathrm{g} / \mathrm{mL}$ de azoxistrobina. A variação na sensibilidade das linhagens, principalmente com a estrobilurina azoxistrobina, possivelmente está relacionada com a variabilidade genética dos isolados de G. citricarpa.

Palavras-chaves: G. citricarpa, Azoxistrobina, Benomil, Mancha Preta dos Citros, Fungicidas

\section{REFERENCES}

1. Azevedo, J.L.; Costa, S.O.P. (1973) Exercícios práticos de genética. Ed. Nacional/EDUSP, São Paulo.

2. Baayen, R.P.; Bonants, P.J.M.; Verkley, G.; Carroll, G.C.; Van Der Aa, M.; Weerdt, M.; Brouwershaven, G.C.; Schutte, G.C.; Maccheroni, Jr., W.; Glienke-Blanco, C.; Azevedo, J.L. (2002). Nonpathogenic strains of citrus black spot fungus, Guignardia citricarpa, identified as a cosmopolitan endophyte of woody plants, Guignardia mangiferae (Phyllosticta capitalensis). Phytopathology, 5: 464-477.

3. Bartlett, D.W.; Clough, J.M.; Godwin, J.R.; Hall, A.A.; Hamer, M.; Parr-Dobrzanski, B. (2002). The strobilurin fungicides. Pest. Manag. Sci., 58: 649-662.

4. Blanco, C. (1999). Guignardia citricarpa Kiely: Análise Genética, cariotípica e interação com o hospedeiro. Piracicaba, 1999, 200p. (PhD. Thesis. Escola Superior de Agricultura Luiz de Queiroz. USP).

5. Coelho, A.S.G. (2005). Softhware Bood. 3.04. 
6. Dekker, J. (1977). Resistance. In: Marsh, R.W. (ed). Systemic fungicides. Butler \& Tanner, London, p. 176-197.

7. Feichtenberger, E. (1996). Mancha preta ou pinta preta dos citros. Laranja \& Cia, 43: 10-11.

8. Feichtenberger E.; Baldassari, R.B.; Spósito, M.B.; Belasque Junior, J. (2005). Doenças dos citros. In: Kimati, H.; Amorin, L.; Rezende, J.A.M.; Bergamin Filho, A.; Camargo, L.E.A. (eds). Manual de fitopatologia. Ceres, São Paulo, v. 2, p. 239-269.

9. Felsenstein, J. (1985). Confidence limits on phylogenies: an approach using the bootstrap. Evolution, 39: 783-791.

10. Ghini, R.; Kimati, H. (2000). Resistência de Fungos a Fungicidas. Embrapa-CNPMA, Jaguariúna, 78p.

11. Glienke, C.; Christo, D. de; Stringari, D.; Maccheroni Jr, W.; Azevedo, J.L. (2009). High Molecular Diversity of the Fungus Guignardia citricarpa and Guignardia mangiferae and New Primers for the Diagnosis of the Citrus Black Spot. Brazilian Archives of Biology and Technology (in press).

12. Glienke-Blanco, C.; Aguilar-Vildoso, C.I.; Vieira, M.L.C.; Barroso, P.A.V.; Azevedo, J.L. (2002). Genetic variability in the endophytic fungus Guignardia citricarpa isolated from citrus plants. Genet. Mol. Biol., 25: 251-255.

13. Goes, A. (2002). Efeito da combinação de fungicidas sistêmicos e protetores no controle da mancha preta dos frutos cítricos causados por Guignardia citricarpa. Summa Phytopathol., 28: 09-13.

14. Herbert, J.A.; Grech, N.M. (1985). A strain of Guignardia citricarpa, the citrus black spot pathogen, resistant to benomyl in South Africa. Plant Dis., 69: 1007.

15. Kimati, H. (1987). Resistência de fitopatógenos a substâncias químicas usadas no controle de doenças de plantas. Summa Phytopathol., 13: 72-74.

16. Kotzé, J.M. (1981). Epidemiology and control of citrus black spot in South Africa. Plant Dis., 65: 249-292.

17. Mantel N. (1967). The detection of disease clustering and a generalized regression approach. Cancer Res., 27: 209-220.

18. Martins, F.T.; Oliveira, A.M.R.; Duarte, V. (1998). Resistência de Guignardia citricarpa ao fungicida benomyl. Fitopatol. Bras., 23 (supl. 1): 256.
19. Orbach, M.J.; Porro, E.B.; Yanofsky, C. (1986). Cloning and characterization of the gene for $\beta$-tubulin from a benomyl-resistant mutant of Neurospora crassa and its use as a dominant selectable marker. Mol. Cell Biol., 6: 2452-2461.

20. Pontecorvo, G.; Roper, J.A.; Hemmons, L.M.; Mac Donald, K.D.; Bufton, A.W.J. (1953). The genetics of Aspergillus nidulans. Adv Genet., 5: 141-238.

21. Raeder, U.; Broda, P. (1985). Rapid preparation of DNA from filamentous fungi. Lett. Appl. Microbiol., 1: 17-20.

22. Robbs; C.F.; Bittencourt, A.M. (1995). A mancha preta dos frutos: um dos fatores limitantes à produção citrícola do Estado do Rio de Janeiro. Embrapa-CTAA, Guaratiba, Comunicado Técnico, 19: 1-5.

23. Rodrigues, M.B.C.; Andreote, F.D.; Spósito, M.B.; Aguillar-Vildoso, C.I.; Araújo, W.L.; Pizzirani-Kleiner, A.A. (2007). Resistência a benzimidazóis por Guignardia citricarpa. Pesq. Agropec. Bras., 42 323-327.

24. Rohlf, F.J. (1988). NTSYS-PC Numerical taxonomy and multivariate analysis system. Exeter Publishing, New York.

25. Schutte, G.C.; Beeton, K.V.; Kotzé, J.M. (1997). Rind stippling on Valencia oranges by copper fungicides used for control of citrus black spot in South Africa. Plant Dis., 81: 851-854.

26. Schutte, G.C., Mansfield, R.I., Smith, H.; Beeton, K.V. (2003). Application of azoxystrobin for control of benomyl-resistant Guignardia citricarpa on 'Valencia' oranges in South Africa. Plant Dis., 87: 784-788.

27. Sheir-Neiss, G.; Lai, M.H.; Morris, N.R. (1978). Identification of a gene for $\beta$-tubulin in Aspergillus nidulans. Cell, 15: 639-647.

28. Sneath, P.H.A.; Sokal, R.R. (1973). Numerical Taxonomy. San Francisco: W. H. Feeman and Company, London, 573 p.

29. Thomas, J.F.; Neff, N.F.; Botstein, D. (1985). Isolation and characterization of mutants in the $\beta$-tubulin gene of Saccharomyces cerevisae. Genetics, 112: 715-734.

30. Van Tuyl, J.M. (1977). Genetics of fungal resistance to systemic fungicides. H. Veenman, H.; Zonen, B.V., Wageningen, The Netherlands, $136 \mathrm{p}$. 